\title{
Article
}

\section{Redescription of Stolephorus ronquilloi Wongratana, 1983 and Description of Stolephorus hindustanensis, a New Anchovy from the Western Coast of India (Teleostei: Clupeiformes: Engraulidae) ${ }^{\dagger}$}

\author{
Harutaka Hata ${ }^{1, *}$ and Hiroyuki Motomura ${ }^{2}$ \\ 1 Center for Molecular Biodiversity Research, National Museum of Nature and Science, 4-1-1 Amakubo, \\ Tsukuba 305-0005, Japan \\ 2 The Kagoshima University Museum, 1-21-30 Korimoto, Kagoshima 890-0065, Japan; \\ motomura@kaum.kagoshima-u.ac.jp \\ * Correspondence: k2795502@kadai.jp \\ $+\quad$ This article is registered in ZooBank under urn:lsid:zoobank.org:pub:7A95E42B-6A4B-45E4-BA1A- \\ 1E480AB28A5D. Stolephorus hindustanensis is registered in ZooBank under \\ urn:lsid:zoobank.org:act:0474C717-034E-425B-867A-87308CAE7AC9.
}

check for updates

Citation: Hata, H.; Motomura, H. Redescription of Stolephorus ronquilloi Wongratana, 1983 and Description of Stolephorus hindustanensis, a New Anchovy from the Western Coast of India (Teleostei: Clupeiformes:

Engraulidae). Taxonomy 2022, 2,

124-135. https://doi.org/10.3390/ taxonomy2010010

Academic Editor: Phillip Lobel

Received: 4 February 2022

Accepted: 3 March 2022

Published: 6 March 2022

Publisher's Note: MDPI stays neutral with regard to jurisdictional claims in published maps and institutional affiliations.

Copyright: () 2022 by the authors. Licensee MDPI, Basel, Switzerland. This article is an open access article distributed under the terms and conditions of the Creative Commons Attribution (CC BY) license (https:// creativecommons.org/licenses/by/ $4.0 /)$.

\begin{abstract}
The new anchovy Stolephorus hindustanensis n. sp., described on the basis of 11 specimens collected from Mumbai, western coast of India, closely resembles Stolephorus ronquilloi Wongratana, 1983 in sharing an indented preopercle posterior margin, long maxilla extending beyond the preopercle posterior margin, double pigmented lines on the dorsum behind the dorsal fin, and lacking a predorsal scute. However, the new species differs from S. ronquilloi in having lower counts of gill rakers on the first and second gill arches, higher counts of total vertebrae, a deeper body, greater distances between the snout tip and anal-fin origin, origins of the dorsal and anal fins, and pelvicfin insertion and anal-fin origin, and longer pelvic fin, third dorsal-fin ray, third anal-fin ray, and postorbital length.
\end{abstract}

Keywords: taxonomy; Actinopterygii; Clupeomorpha; Indian Ocean

\section{Introduction}

Stolephorus Lacepède, 1803, an Indo-Pacific genus of marine and/or brackish water anchovies (Clupeiformes: Engraulidae), was reviewed by Whitehead et al., (1988), who recognized 18 valid and one undescribed species. Currently, the genus comprises 37 valid species [1-18], seven of which (including a number described in recent studies [16,18]) are diagnosed by an indented preopercle posterior margin. In addition, 11 specimens with a similarly indented preopercle margin, collected from the western coast of India and found during an ongoing revisionary study of the genus, are described herein as a new species of Stolephorus. The new species closely resembles Stolephorus ronquilloi Wongratana, 1983, endemic to the Philippines, in sharing the similar coloration and lacking a predorsal scute. As detailed morphological data of $S$. ronquilloi has never been provided since the original description, the species is redescribed herein.

\section{Materials and Methods}

Counts and proportional measurements followed Hata and Motomura (2017) [19]. All measurements were made to the nearest $0.01 \mathrm{~mm}$ using digital calipers. Standard and head lengths are abbreviated as SL and HL, respectively. "Pelvic scute" refers to a scute joined to the pelvic girdle, and "prepelvic scute", "postpelvic scute" and "predorsal scute" to hard spine-like scutes anterior to the pelvic fin, posterior to the pelvic fin, and just anterior to the dorsal-fin origin, respectively. Osteological characters, including vertebral counts, were 
observed on 11 specimens each of $S$. ronquilloi and the new species. Abbreviations are as follows-SL: standard length; HL: head length; and UGR, LGR, and TGR: rakers on upper limb, lower limb, and total gill rakers, respectively, with associated numbers indicating the specific gill arch. Institutional codes follow Sabaj (2020) [20].

\section{Stolephorus ronquilloi Wongratana, 1983}

[English name: Ronquillo's Anchovy]

Figure 1; Tables 1-3

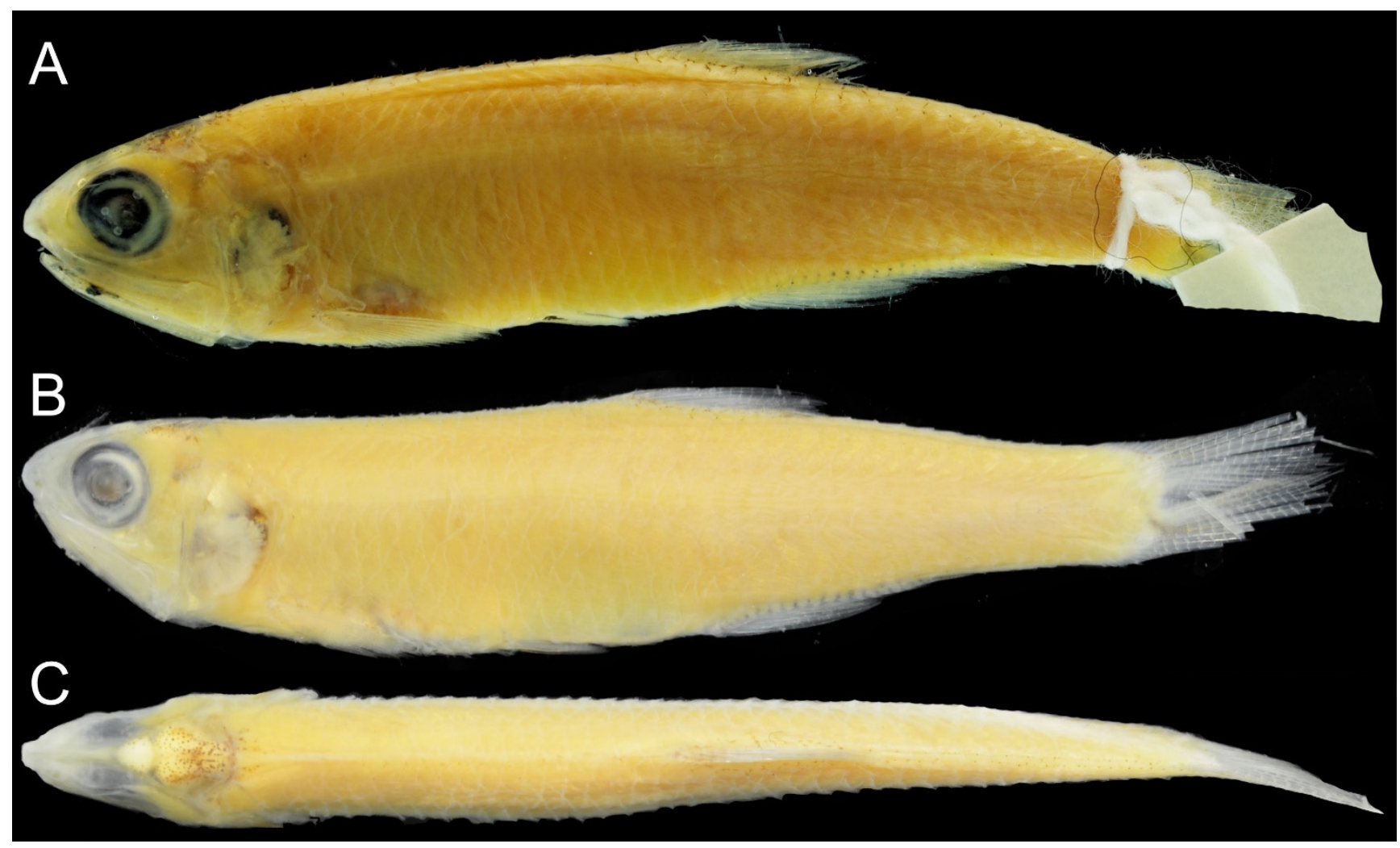

Figure 1. (A) Lateral view of the holotype of Stolephorus ronquilloi (BMNH1969.5.30.88, $48.7 \mathrm{~mm}$ SL; Luzon, Philippines); (B) lateral and (C) dorsal views of the non-type specimen (USNM 23845, 44.3 mm SL, Luzon, Philippines).

Table 1. Meristics of specimens of Stolephorus ronquilloi and Stolephorus hindustanensis n. sp. Bold characters indicate non-overlapping meristics between the two species.

\begin{tabular}{|c|c|c|c|c|c|c|}
\hline & \multicolumn{3}{|c|}{ Stolephorus ronquilloi } & \multicolumn{3}{|c|}{ Stolephorus hindustanensis n. sp. } \\
\hline & Holotype & Non-Types & & Holotype & Paratypes & \\
\hline & $\begin{array}{c}\text { BMNH } \\
\text { 1969.5.30.88 }\end{array}$ & $n=11$ & & $\begin{array}{c}\text { BMNH } \\
\text { 1969.4.22.1648 }\end{array}$ & $n=10$ & \\
\hline Standard length (mm) & 48.7 & $43.6-52.0$ & Modes \pm SD & 53.1 & $47.3-59.9$ & Modes $\pm \mathrm{SD}$ \\
\hline Dorsal-fin rays (unbranched) & 3 & 3 & $3 \pm 0$ & 3 & 3 & $3 \pm 0$ \\
\hline Dorsal-fin rays (branched) & 13 & $12-13$ & $13 \pm 0.4$ & 13 & $12-13$ & $13 \pm 0.4$ \\
\hline Anal-fin rays (unbranched) & 3 & 3 & $3 \pm 0$ & 3 & 3 & $3 \pm 0$ \\
\hline Anal-fin rays (branched) & 18 & $16-18$ & $18 \pm 0.8$ & 18 & $16-18$ & $18 \pm 0.6$ \\
\hline Pectoral-fin rays (unbranched) & 1 & 1 & $1 \pm 0$ & 1 & 1 & $1 \pm 0$ \\
\hline Pectoral-fin rays (branched) & 11 & $11-12$ & $11 \pm 0.5$ & 12 & $10-12$ & $12 \pm 0.7$ \\
\hline Pelvic-fin rays (unbranched) & 1 & 1 & $1 \pm 0$ & 1 & 1 & $1 \pm 0$ \\
\hline Pelvic-fin rays (branched) & 6 & 6 & $6 \pm 0$ & 6 & 6 & $6 \pm 0$ \\
\hline Gill rakers on 1st gill arch (upper) & 20 & $18-21$ & $20 \pm 0.7$ & 19 & $17-20$ & $19 \pm 0.8$ \\
\hline
\end{tabular}


Table 1. Cont.

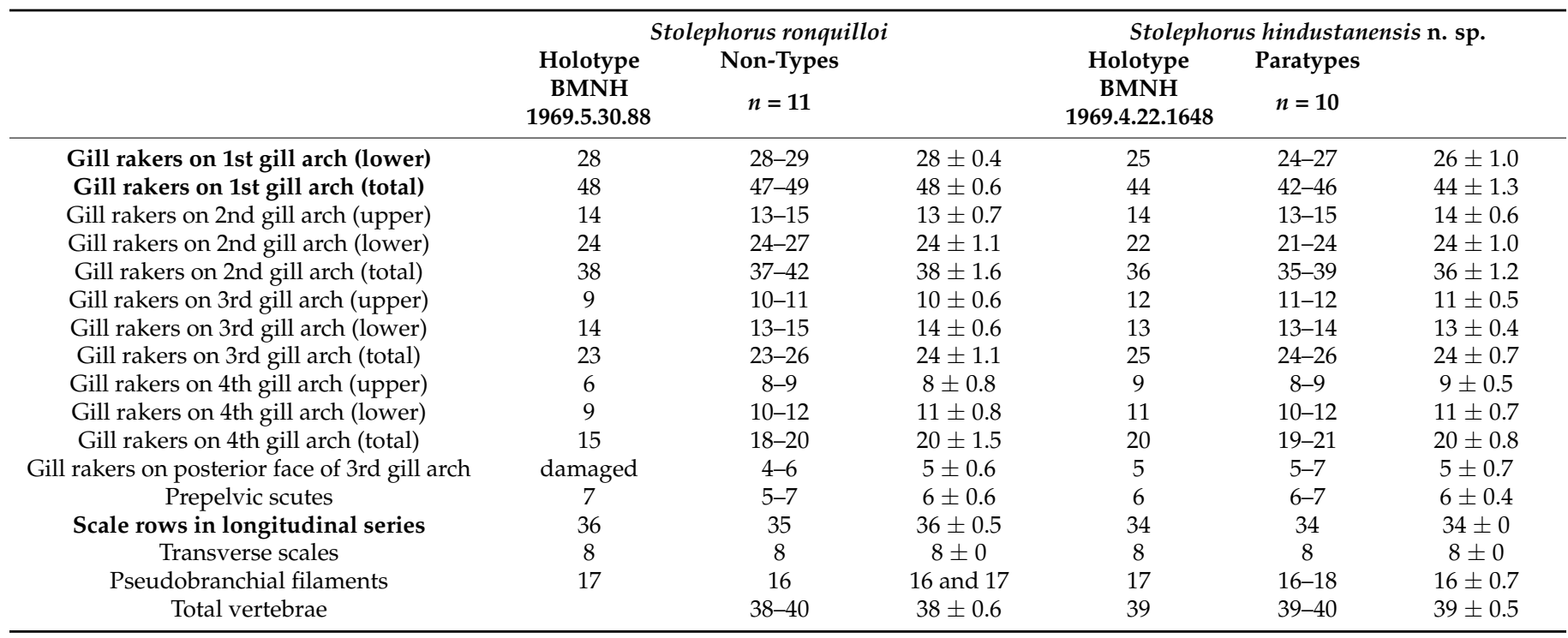

Table 2. Morphometrics of specimens of Stolephorus ronquilloi and Stolephorus hindustanensis n. sp. Bold characters indicate non-overlapping morphometrics between the two species.

\begin{tabular}{|c|c|c|c|c|c|c|}
\hline & \multicolumn{3}{|c|}{ Stolephorus ronquilloi } & \multicolumn{3}{|c|}{ Stolephorus hindustanensis n. sp. } \\
\hline & $\begin{array}{c}\text { Holotype } \\
\text { BMNH } \\
\text { 1969.5.30.88 }\end{array}$ & $\begin{array}{c}\text { Non-Types } \\
n=11\end{array}$ & & $\begin{array}{c}\text { Holotype } \\
\text { BMNH } \\
\text { 1969.4.22.1648 }\end{array}$ & $\begin{array}{l}\text { Paratypes } \\
\qquad n=10\end{array}$ & \\
\hline $\begin{array}{c}\text { Standard length }(\mathrm{mm}) \\
\text { As \% SL }\end{array}$ & 48.7 & $43.6-52.0$ & Means \pm SD & 53.1 & $47.3-59.9$ & Means \pm SD \\
\hline Head length (HL) & 25.2 & $24.2-26.2$ & $25.2 \pm 0.6$ & 25.2 & $24.8-26.2$ & $25.4 \pm 0.4$ \\
\hline Body depth & 21.1 & $21.3-22.6$ & $21.9 \pm 0.5$ & 23.5 & $23.3-25.3$ & $24.0 \pm 0.7$ \\
\hline Pre-dorsal fin length & 56.0 & $53.7-57.5$ & $55.9 \pm 1.1$ & 56.8 & $54.9-56.2$ & $55.6 \pm 0.6$ \\
\hline Snout tip to pectoral-fin insertion & 27.4 & $26.1-27.6$ & $27.1 \pm 0.4$ & 26.3 & $26.3-28.2$ & $27.2 \pm 0.7$ \\
\hline Snout tip to pelvic-fin insertion & 44.4 & $44.2-46.4$ & $45.4 \pm 0.7$ & 45.6 & $45.3-48.2$ & $46.7 \pm 1.0$ \\
\hline Snout tip to anal-fin origin & 62.3 & $62.8-64.0$ & $63.4 \pm 0.5$ & 65.4 & $65.1-67.1$ & $66.0 \pm 0.7$ \\
\hline Dorsal-fin base length & 15.2 & $12.9-14.8$ & $14.3 \pm 0.7$ & 13.6 & $13.5-15.0$ & $14.3 \pm 0.5$ \\
\hline Anal-fin base length & 20.5 & $19.5-20.9$ & $20.2 \pm 0.5$ & 19.4 & $19.2-20.8$ & $19.8 \pm 0.5$ \\
\hline Caudal-peduncle length & 17.5 & $16.8-18.8$ & $17.6 \pm 0.6$ & 17.5 & $17.1-20.0$ & $18.4 \pm 1.1$ \\
\hline Caudal-peduncle depth & 10.5 & $10.1-11.0$ & $10.6 \pm 0.3$ & 11.0 & $10.6-11.3$ & $11.0 \pm 0.2$ \\
\hline D-P1 & 35.8 & $35.2-38.3$ & $37.0 \pm 0.9$ & 38.4 & $36.9-40.0$ & $38.5 \pm 0.9$ \\
\hline D-P2 & 25.2 & $22.8-26.5$ & $24.9 \pm 1.0$ & 25.6 & $25.2-27.6$ & $26.1 \pm 0.9$ \\
\hline D-A & 22.2 & $21.2-22.9$ & $22.4 \pm 0.5$ & 24.3 & $23.4-25.7$ & $24.4 \pm 0.8$ \\
\hline P1-P2 & 18.6 & $18.2-21.6$ & $19.8 \pm 1.1$ & 20.7 & $20.6-21.6$ & $21.1 \pm 0.3$ \\
\hline $\mathrm{P} 2-\mathrm{A}$ & 17.8 & $16.6-19.4$ & $18.0 \pm 0.7$ & 19.0 & $19.0-21.5$ & $20.4 \pm 1.0$ \\
\hline Pectoral-fin length & 15.2 & $15.0-15.7$ & $15.4 \pm 0.3$ & broken & 15.7 & $15.7 \pm 0$ \\
\hline Pelvic-fin length & 8.0 & $8.1-9.0$ & $8.5 \pm 0.3$ & 9.8 & $9.5-10.1$ & $9.8 \pm 0.2$ \\
\hline Maxilla length & 21.4 & $20.2-21.6$ & $21.0 \pm 0.5$ & 20.3 & $20.5-22.3$ & $21.1 \pm 0.8$ \\
\hline Lower-jaw length & 16.9 & $15.7-17.0$ & $16.4 \pm 0.4$ & 15.9 & $15.6-17.0$ & $16.4 \pm 0.5$ \\
\hline Supramaxilla end to maxilla end & 4.2 & $4.7-6.2$ & $5.6 \pm 0.5$ & 6.3 & $5.7-6.7$ & $6.3 \pm 0.3$ \\
\hline 1st dorsal-fin ray length & 2.1 & $1.0-2.2$ & $1.7 \pm 0.4$ & 1.5 & $1.2-1.8$ & $1.5 \pm 0.2$ \\
\hline 2nd dorsal-fin ray length & 6.4 & $7.3-9.0$ & $7.7 \pm 0.8$ & broken & $7.2-8.0$ & $7.7 \pm 0.3$ \\
\hline 3rd dorsal-fin ray length & damaged & $16.5-17.0$ & $16.8 \pm 0.2$ & broken & $18.6-18.8$ & $18.7 \pm 0.1$ \\
\hline 1st anal-fin ray length & 2.1 & $1.3-2.2$ & $1.8 \pm 0.2$ & 1.8 & $1.3-2.1$ & $1.7 \pm 0.2$ \\
\hline 2nd anal-fin ray length & damaged & $5.1-6.1$ & $5.5 \pm 0.5$ & broken & $4.5-6.0$ & $5.3 \pm 0.6$ \\
\hline $\begin{array}{c}\text { 3rd anal-fin ray length } \\
\text { as } \% \text { of HL }\end{array}$ & 13.7 & $13.4-14.9$ & $14.1 \pm 0.5$ & broken & $15.7-16.1$ & $15.8 \pm 0.2$ \\
\hline Maximum orbit diameter & 36.5 & $33.2-36.9$ & $35.5 \pm 1.0$ & 33.7 & $32.9-34.4$ & $33.6 \pm 0.4$ \\
\hline Eye diameter & 31.8 & $29.4-32.2$ & $30.8 \pm 0.9$ & 29.8 & $27.4-30.8$ & $29.5 \pm 1.0$ \\
\hline Snout length & 15.2 & $14.5-16.0$ & $15.3 \pm 0.4$ & 14.6 & $14.1-15.4$ & $14.6 \pm 0.3$ \\
\hline Interorbital width & 22.9 & $20.8-23.9$ & $22.3 \pm 0.8$ & 23.2 & $22.0-24.0$ & $23.1 \pm 0.6$ \\
\hline Postorbital length & 47.2 & $48.2-51.3$ & $49.4 \pm 1.2$ & 53.5 & $51.0-53.5$ & $52.5 \pm 0.8$ \\
\hline
\end{tabular}

Abbreviations: D-P1 (distance from dorsal-fin origin to pectoral-fin insertion); D-P2 (distance from dorsal-fin origin to pelvic-fin insertion); D-A (distance between origins of dorsal- and anal fins); P1-P2 (distance between insertions of pectoral- and pelvic fins); P2-A (distance between pelvic-fin insertion and anal-fin origin). 
Table 3. Frequency distribution of total vertebral numbers in Stolephorus ronquilloi and Stolephorus hindustanensis $\mathrm{n}$. $\mathrm{sp}$.

\begin{tabular}{ccccc}
\hline & \multicolumn{4}{c}{ Total Vertebrae } \\
\cline { 2 - 5 } & & 38 & 39 & 40 \\
\hline Stolephorus ronquilloi & $n=11$ & 8 & 2 & 1 \\
Stolephorus hindustanensis n. sp. & $n=11$ & & 7 & 4 \\
\hline
\end{tabular}

Stolephorus ronquilloi Wongratana, 1983 [1]: 399, figure 17 (type locality: Manila Bay, Luzon, Philippines; paratype localities: Mindanao and Luzon, Philippines); Wongratana 1987 [3]: 8 (Philippines); Whitehead et al., 1988 [4]: 418, unnumbered figure (Philippines); Wongratana et al., 1999 [5], 1740, unnumbered figure (Philippines); Munroe and Nizinski 2000 [21]: 588 (South China Sea); Hata et al., 2020 [16]: 10 (Manila Bay, Philippines); Hata and Motomura 2021 [13]: 11 (Philippines).

Holotype. BMNH1969.5.30.88, 48.7 mm SL, Manilla Bay, Luzon, Philippines, coll. by I. A. Ronquillo.

Non-type specimens. USNM 238425, 11 specimens, 43.6-52.0 mm SL, Manila Bay, Manila, Luzon, Philippines.

Diagnosis. A species of Stolephorus with the following combination of characters: 1UGR 18-21 (modally 20), 1LGR 28-29 (28), 1TGR 47-49 (48); 2UGR 13-15 (13), 2LGR 24-27 (24), 2TGR 37-42 (38); 3UGR 9-11 (10), 3LGR 13-15 (14), 3TGR 23-26 (24); 4UGR 6-9 (8), 4LGR 9-12 (11), 4TGR 15-20 (20); prepelvic scutes 5-7 (6); total vertebrae 38-40 (38); long maxilla, posterior tip just reaching or slightly short of posterior margin of opercle; no predorsal scutes; pelvic scute without spine; posterior margin of preopercle indented; paired dark patches on parietal area, with a few following pigment spots; distinct double pigment lines along dorsum posterior to dorsal fin; black spots below eye and lower-jaw tip absent; body rather elongate, $21.1-22.6 \%$ of SL; pre-anal-fin length short, $62.3-64.0 \%$ of SL; distance between origins of dorsal and anal fins rather short, $21.2-22.9 \%$ of SL; distance between pelvic-fin insertion to anal-fin origin relatively short, $16.6-19.4 \%$ of SL; pelvic fin rather short, $8.1-9.0 \%$ of SL; third dorsal-fin ray short, $16.5-17.0 \%$ of SL; third anal-fin ray short, $13.4-14.9 \%$ of SL; postorbital area relatively short, $48.2-51.3 \%$ of HL.

Description. Data for holotype presented first, followed by data for other specimens in parentheses (if different). Counts and measurements expressed as percentages of SL or HL are given in Tables 1 and 2. Body laterally compressed, elongate, deepest at the dorsal-fin origin. Dorsal profile of head and body slightly convex from snout tip to dorsal-fin origin, gently lowering to the uppermost point of the caudal-fin base. Ventral profile of head and body slightly convex from lower-jaw tip to pelvic-fin insertion, thereafter slowly rising to lowermost point of the caudal-fin base. Abdomen somewhat rounded, covered with seven (five or seven) spine-like scutes. Pelvic scute without a spine. Postpelvic and predorsal scutes absent. Anus just anterior to anal-fin origin. Snout tip rounded; snout length less than eye diameter. Mouth large, inferior, ventral to body axis, extending backward beyond posterior margin of eye. Maxilla rather long, its posterior tip pointed, just reaching (short of or slightly beyond) posterior margin of preopercle. Lower jaw slender. Single row of conical teeth on each jaw and palatines. Several distinct conical teeth on vomer. Teeth patch on pterygoid. One or two rows of conical teeth on upper edges of basihyal and basibranchial. Eye large, round, covered with adipose eyelid, positioned laterally on head above horizontal through pectoral-fin insertion, visible in dorsal view. Pupil round. Orbit elliptical. Nostrils close to each other, anterior to orbit. Posterior margin of preopercle distinctly indented. Subopercle and opercle with smoothly rounded posterior margins. Gill membrane without serrations. Interorbital space flat, width less than eye diameter. Pseudobranchial filaments present, length of longest filament shorter than eye diameter. Gill rakers long, slender, rough, visible from side of head when mouth opened. Single row of asperities on anterior surface of gill rakers. Isthmus muscle long, reaching anteriorly to posterior margin of gill membranes. Urohyal hidden by isthmus muscle, not visible without 
dissection. Gill membranes on each side joined distally, isthmus muscle mostly exposed, not covered by gill membrane. Body scales deciduous, completely lacking on specimens, except for prepelvic scutes. Head scales absent. Lateral line absent. Fins scaleless, except for broad triangular sheath of scales on caudal fin. Dorsal-fin origin posterior to vertical through base of last pelvic-fin ray, slightly posterior to middle of body. Dorsal and anal fins with three anteriormost rays unbranched and closely spaced. First dorsal- and anal-fin rays minute. Anal-fin origin just below base of seventh (seventh to ninth) dorsal-fin ray. Posterior tip of depressed anal fin not reaching caudal-fin base. Uppermost pectoral-fin ray unbranched, inserted below midline of body. Posterior tip of pectoral fin not reaching to pelvic-fin insertion. Dorsal, ventral, and posterior margins of pectoral fin nearly linear. Pelvic fin shorter than pectoral fin, insertion anterior to vertical through dorsal-fin origin. Posterior tip of depressed pelvic fin not reaching to vertical through dorsal-fin origin. Caudal fin forked, posterior tips pointed.

Coloration of preserved specimens. Body uniformly pale yellow. Light ivory longitudinal band running from just behind upper opercular margin to caudal-fin base. Head uniformly light yellow. No black spots on suborbital area. A pair of dark patches on parietal region and a few pigment spots on occipital area. Scale pockets on dorsum with black posterior margin. Melanophores scattered along bases of dorsal and anal fins. Double pigmented lines dorsally posterior to dorsal fin. All fins transparent, melanophores scattered along fin rays of caudal fin and anterior part of dorsal fin. Caudal fin with black upper and posterior margins.

Distribution. Stolephorus ronquilloi is endemic to the Philippines ([1,3-5]; this study; Figure 2).

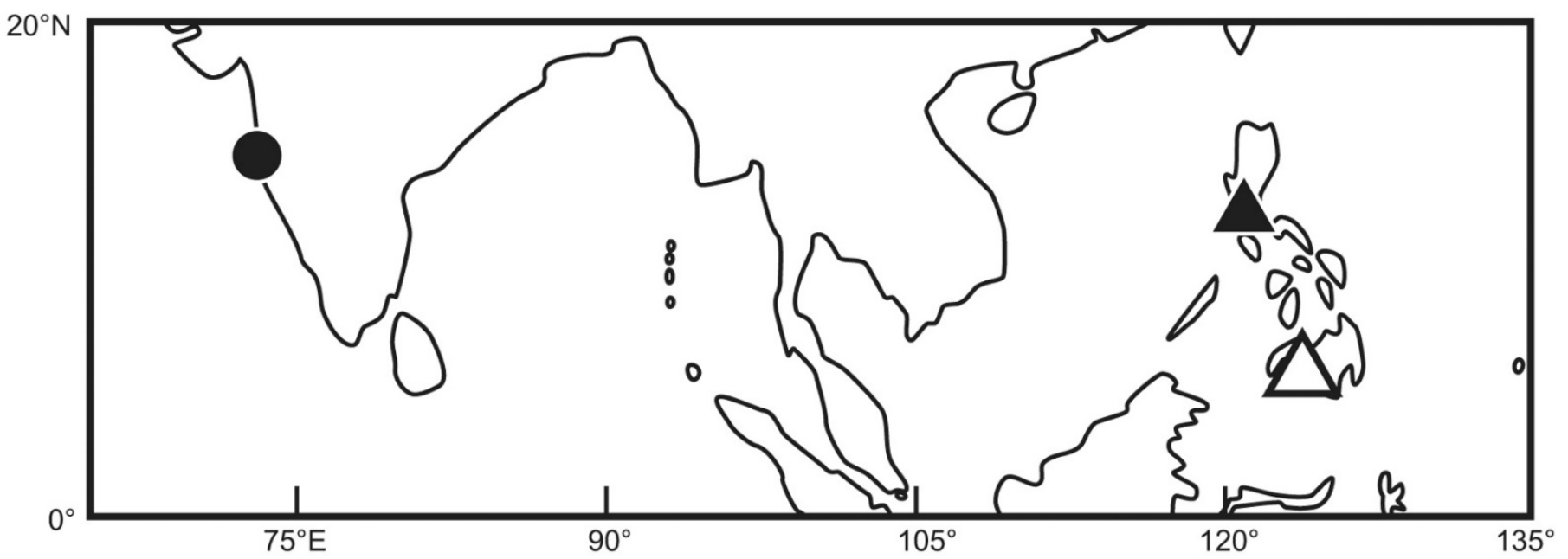

Figure 2. Distributional records of Stolephorus ronquilloi (triangles) And S. hindustanensis n. sp. (circle). Solid symbols based on specimens examined in this study; open symbol based on the original description (Wongratana 1983).

Comparisons. Stolephorus ronquilloi is distinguished from all other congeners, except for Stolephorus acinaces Hata, Lavoué and Motomura, 2020, Stolephorus andhraensis Babu Rao, 1966, Stolephorus bengalensis (Dutt and Babu Rao, 1959), Stolephorus carpentariae (De Vis, 1882), Stolephorus holodon (Boulanger, 1900), Stolephorus tamilensis Gangan, Pavan-Kumar, Jahageerdar and Jaiswar, 2020, and S. hindustanensis n. sp. by an indented preopercle posterior margin, and long maxilla, extending well beyond the preopercle posterior margin ([1-18]; this study). However, S. ronquilloi differs from the other six species in having higher numbers of 1LGR (28 or more in S. ronquilloi vs. 27 or less in the other six, except in $S$. holodon), and double pigmented lines on the dorsum (vs. dorsal lines absent, except in $S$. bengalensis). Stolephorus ronquilloi can also be distinguished from $S$. bengalensis due to the lack of a predorsal scute (vs. spine-like scute located just anterior to the dorsal-fin origin in 
S. bengalensis). Stolephorus ronquilloi differs from S. carpentariae in anal-fin origin position (anal-fin origin just below seventh to ninth dorsal-fin ray origin in S. ronquilloi vs. just below second to six dorsal-fin ray origin in S. carpentariae) and number of branched anal-fin rays (16-18 vs. 19 or 20$)([1,4,5,14,16]$; this study).

Although S. ronquilloi has similar coloration (double dark lines on dorsum behind dorsal fin) to Stolephorus baganensis Delsman, 1931, S. bengalensis, Stolephorus dubiosus Wongratana, 1983, and Stolephorus tri (Bleeker, 1853), the former differs from the other species in lacking a predorsal scute (vs. spine-like scute located just anterior to dorsal-fin origin) $[1,4,5,14]$. Detailed comparisons of $S$. ronquilloi with $S$. hindustanensis n. sp. are given under "Comparisons" following the latter.

Remarks. Stolephorus ronquilloi was described by Wongratana (1983) [1] based on 15 type specimens and 59 non-type specimens collected from the Philippines. Subsequently, the species has appeared in revisional studies of the genus [3,4], or some ichthyofaunal studies (e.g., $[5,21])$. No studies however indicated voucher specimens, except for Hata et al., (2020) [16] who used the holotype of the species to compare with their new species. Because additional specimens have never been reported, non-type specimens reported in this study represent the second record of the species.

\section{Stolephorus hindustanensis n. sp.}

[New English name: Hindustan Anchovy]

Figures 3 and 4; Tables 1-3

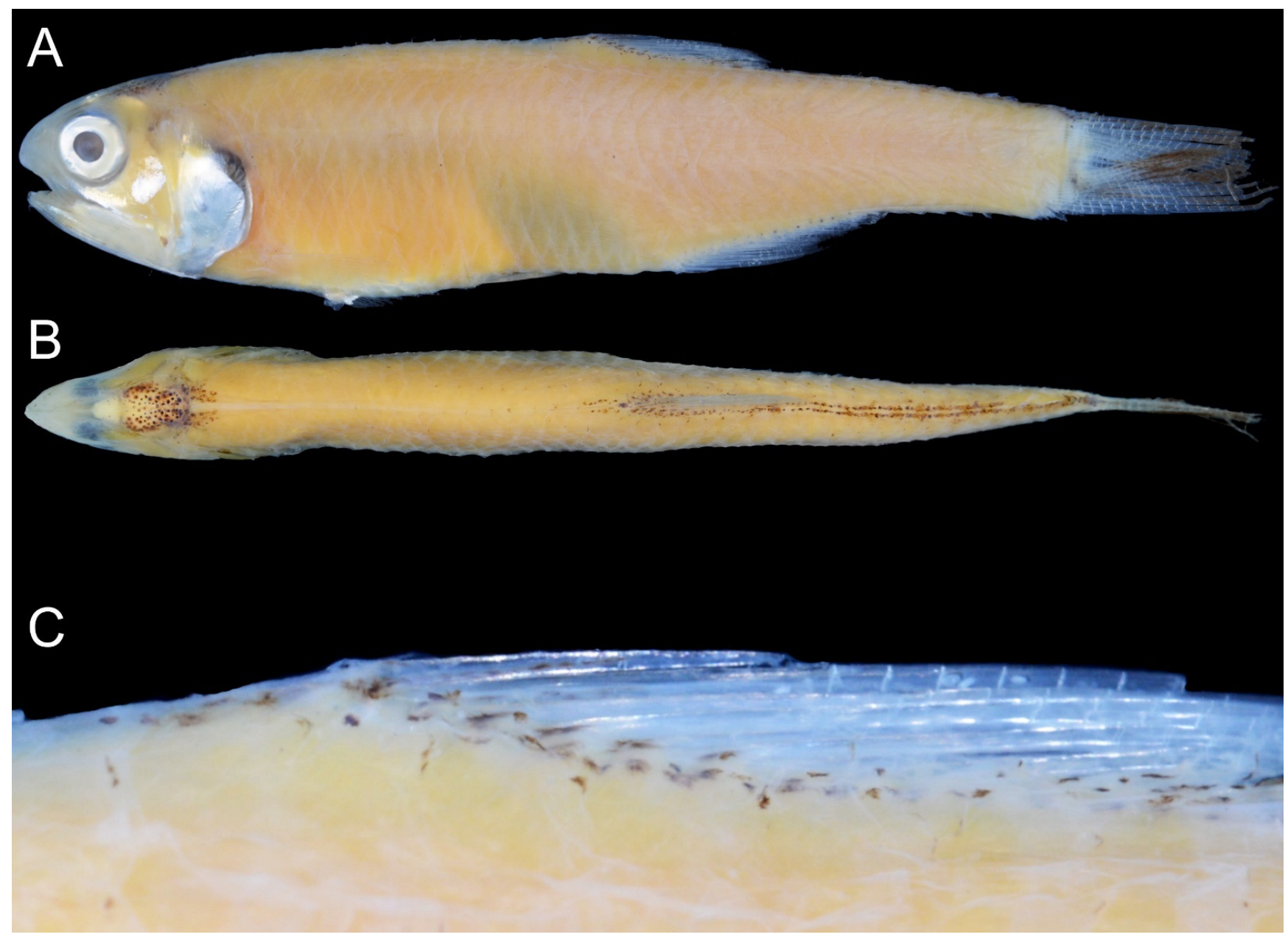

Figure 3. (A) Lateral and (B) dorsal views; and (C) dorsal-fin origin (without scute) of the holotype of S. hindustanensis n. sp. (BMNH 1969.4.22.1648, 53.1 mm SL, Mumbai, India). 
Stolephorus insularis (not of Delsman): Whitehead et al., 1988 [4] (in part): 413 (northwestern part of India).

Holotype. BMNH 1969.4.22.1648, 53.1 mm SL, Sassoon Docks, Mumbai, Maharashtra State, India, collected by R. Ronquillo.

Paratypes. 10 specimens, 47.3-59.9 mm SL: BMNH 1969.4.22.1649-1654, 6 specimens, 49.1-59.9 mm SL, KAUM-I. 165550, 52.0 mm SL, KAUM-I. 165551, 53.0 mm SL, NSMT-P 143988, 47.3 mm SL, NSMT-P 143989, $53.0 \mathrm{~mm}$ SL, collected with the holotype.

Diagnosis. A species of Stolephorus with the following combination of characters: 1UGR 17-20 (modally 19), 1LGR 24-27 (26), 1TGR 42-46 (44); 2UGR 13-15 (14), 2LGR 21-24 (24), 2TGR 35-39 (36); 3UGR 11 or 12 (11), 3LGR 13 or 14 (13), 3TGR 24-26 (24); 4UGR 8 or 9 (9), 4LGR 10-12 (11), 4TGR 19-21 (20); prepelvic scutes 6 or 7 (6); total vertebrae 39 or 40 (39); long maxilla, posterior tip just reaching or slightly short of posterior margin of opercle; no predorsal scutes; pelvic scute without spine; posterior margin of preopercle indented; paired dark patches on parietal area, with a few following pigment spots; distinct double pigment lines along dorsum posterior to dorsal fin; black spots below eye and lower-jaw tip absent; body deep, 23.3-25.3\% of SL; pre-anal-fin length relatively long, 65.1-67.1\% of SL; distance between origins of dorsal and anal fins long, $23.4-25.7 \%$ of SL; distance between pelvic-fin insertion to anal-fin origin relatively long, $19.0-21.5 \%$ of SL; pelvic fin long, $9.5-10.1 \%$ of SL; third dorsal-fin ray long, $18.6-18.8 \%$ of SL; third anal-fin ray long, $15.7-16.1 \%$ of SL; postorbital area long, $51.0-53.5 \%$ of HL.

Description. Data for holotype presented first, followed by data for paratypes in parentheses (if different). Counts and measurements expressed as percentages of SL or HL are given in Tables 1 and 2. Body laterally compressed, elongate, deepest at dorsalfin origin. Dorsal profile of head and body slightly convex from snout tip to dorsal-fin origin, gently lowering to uppermost point of caudal-fin base. Ventral profile of head and body slightly convex from lower-jaw tip to pelvic-fin insertion, thereafter slowly rising to lowermost point of caudal-fin base. Abdomen somewhat rounded, covered with six (six or seven) spine-like scutes. Pelvic scute without spine. Postpelvic and predorsal scutes absent (Figure 3C). Anus just anterior to anal-fin origin. Snout tip rounded; snout length less than eye diameter. Mouth large, inferior, ventral to body axis, extending backward beyond posterior margin of eye. Maxilla rather long, its posterior tip pointed, just reaching (short of or slightly beyond) posterior margin of preopercle (Figure 4). Lower jaw slender. Single row of conical teeth on each jaw and palatines. Several distinct conical teeth on vomer. Teeth patch on pterygoid. One or two rows of conical teeth on upper edges of basihyal and basibranchial. Eye large, round, covered with adipose eyelid, positioned laterally on head above horizontal through pectoral-fin insertion, visible in dorsal view. Pupil round. Orbit elliptical. Nostrils close to each other, anterior to orbit. Posterior margin of preopercle distinctly indented (Figure 4). Subopercle and opercle with smoothly rounded posterior margins. Gill membrane without serrations. Interorbital space flat, width less than eye diameter. Pseudobranchial filaments present, longest filament length less than eye diameter. Gill rakers long, slender, rough, visible from side of head when mouth opened. Single row of asperities on anterior surface of gill rakers. Isthmus muscle long, reaching anteriorly to posterior margin of gill membranes. Urohyal hidden by isthmus muscle, not visible without dissection. Gill membranes on each side joined distally, isthmus muscle mostly exposed, not covered by gill membrane. Body scales deciduous, completely lacking on specimens, except for prepelvic scutes. Head scales absent. Lateral line absent. Fins scaleless, except for broad triangular sheath of scales on caudal fin. Dorsal-fin origin posterior to vertical through base of last pelvic-fin ray, slightly posterior to middle of body. Dorsal and anal fins with three anteriormost rays unbranched and closely spaced. First dorsal- and anal-fin rays minute. Anal-fin origin just below base of tenth (eighth to tenth) dorsal-fin ray. Posterior tip of depressed anal fin not reaching caudal-fin base. Uppermost pectoral-fin ray unbranched, inserted below midline of body. Posterior tip of pectoral fin not reaching to pelvic-fin insertion. Dorsal, ventral, and posterior margins of pectoral fin nearly linear. Pelvic fin shorter than pectoral fin, insertion anterior to vertical through dorsal-fin origin. Posterior 
tip of depressed pelvic fin not reaching to vertical through dorsal-fin origin. Caudal fin forked, posterior tips pointed.

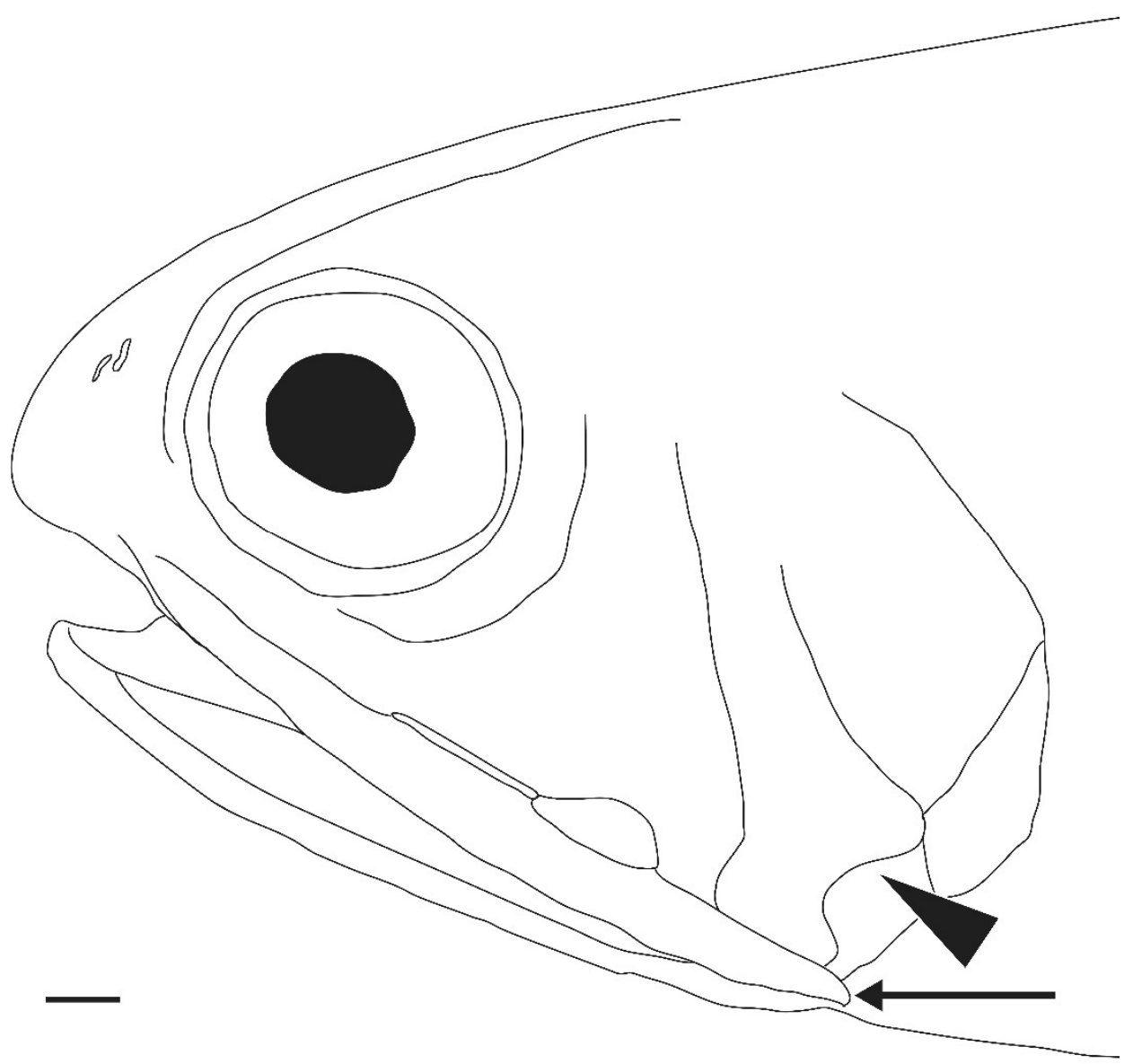

Figure 4. Lateral view of the head of holotype of S. hindustanensis n. sp. (BMNH 1969.4.22.1648, 53.1 mm SL, Mumbai, India). Triangle and arrow indicate indented preopercle posterior margin, and posterior tip of maxilla, respectively. Bar indicates $1 \mathrm{~mm}$.

Coloration of preserved specimens. Body uniformly pale yellow. Light ivory longitudinal band running from just behind upper opercular margin to caudal-fin base. Cheek and opercle silver. A few melanophores scattered on dorsum of snout. No black spots on suborbital area. A pair of distinct dark patches on parietal region, a few pigment spots on occipital area. Scale pockets on dorsum with black posterior margin. Melanophores scattered along bases of dorsal and anal fins. Double pigmented lines dorsally posterior to dorsal fin. All fins transparent, melanophores scattered along fin rays of caudal fin and anterior part of dorsal fin. Caudal fin with black upper and posterior margins.

Distribution. Stolephorus hindustanensis n. sp. is currently known only from Mumbai, northwestern coat of India (Figure 2).

Etymology. The specific name "hindustanensis" is derived from the Persian name for India (Hindustan), the type locality of the new species.

Comparisons. The new species is assignable to the genus Stolephorus, as defined by Whitehead et al. (1988) [4] and Wongratana et al. (1999) [5], having a long isthmus muscle reaching anteriorly to the posterior margin of the gill membrane, and hidden urohyal and prepelvic scutes, and postpelvic scutes absent. Stolephorus hindustanensis n. sp. most closely resembles $S$. ronquilloi, the two species sharing a long maxilla with the posterior tip slightly short of or just reaching the posterior border of the preopercle, indented preopercle posterior margin (Figure 4), and the dorsum with double pigmented lines behind the dorsal fin. Both species lack a predorsal scute, a spine on the pelvic scute, and black spots below the eye and lower-jaw tip $([1,4,5,14,16]$; this study). Moreover, the new species differs 
from $S$. ronquilloi in having lower numbers of gill rakers on the first and second gill arches (Table 1; Figure 5), higher numbers of total vertebrae [39 or 40 (modally 39) vs. 38-40 (modally 38) (Tables 1 and 3)], a deeper body (23.3-25.3\% of SL in S. hindustanensis vs. $21.1-26.6 \%$ in $S$. ronquilloi), greater distances between the snout tip and anal-fin origin (65.1-67.1\% of SL vs. $62.3-64.0 \%)$, origins of the dorsal and anal fins $(23.4-25.7 \%$ of SL vs. $21.2-22.9 \%)$, and pelvic-fin insertion and anal-fin origin (19.0-21.5\% of SL vs. 16.6-19.4\%), and longer pelvic fin (9.5-10.1\% of SL vs. $8.0-9.0 \%)$, third dorsal-fin ray (18.6-18.8\% of SL vs. $16.5-17.0 \%)$, third anal-fin ray (15.7-16.1\% of SL vs. 13.4-14.9\%), and postorbital lengths (51.0-53.5\% of HL vs. 47.2-51.3\%) (Table 2; Figure 6).
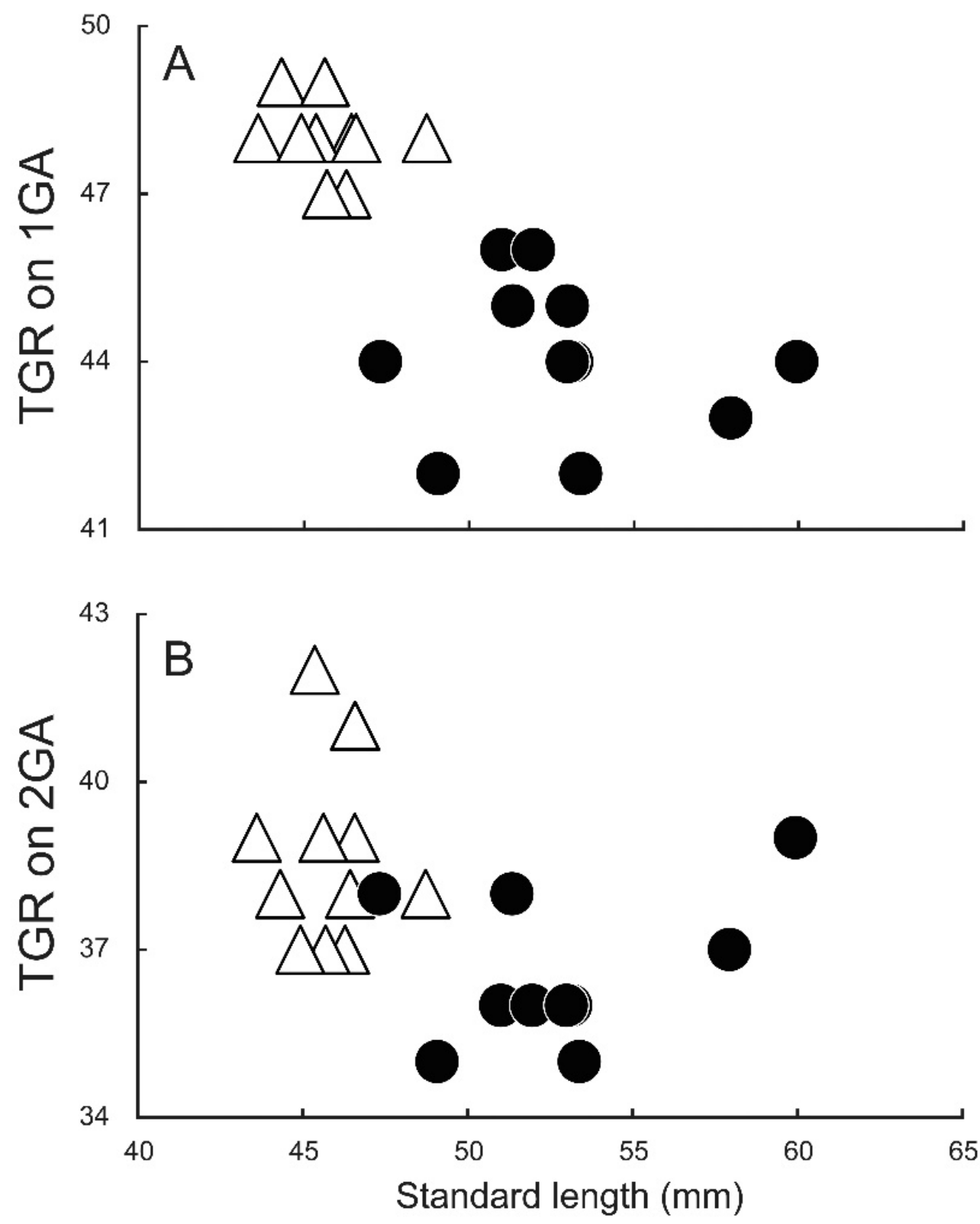

Figure 5. Relationships of total gill raker numbers (TGR) on (A) first gill arch (1GA) and (B) second gill arch (2GA) to standard length in Stolephorus ronquilloi (triangles) and S. hindustanensis (circles) n. sp. 

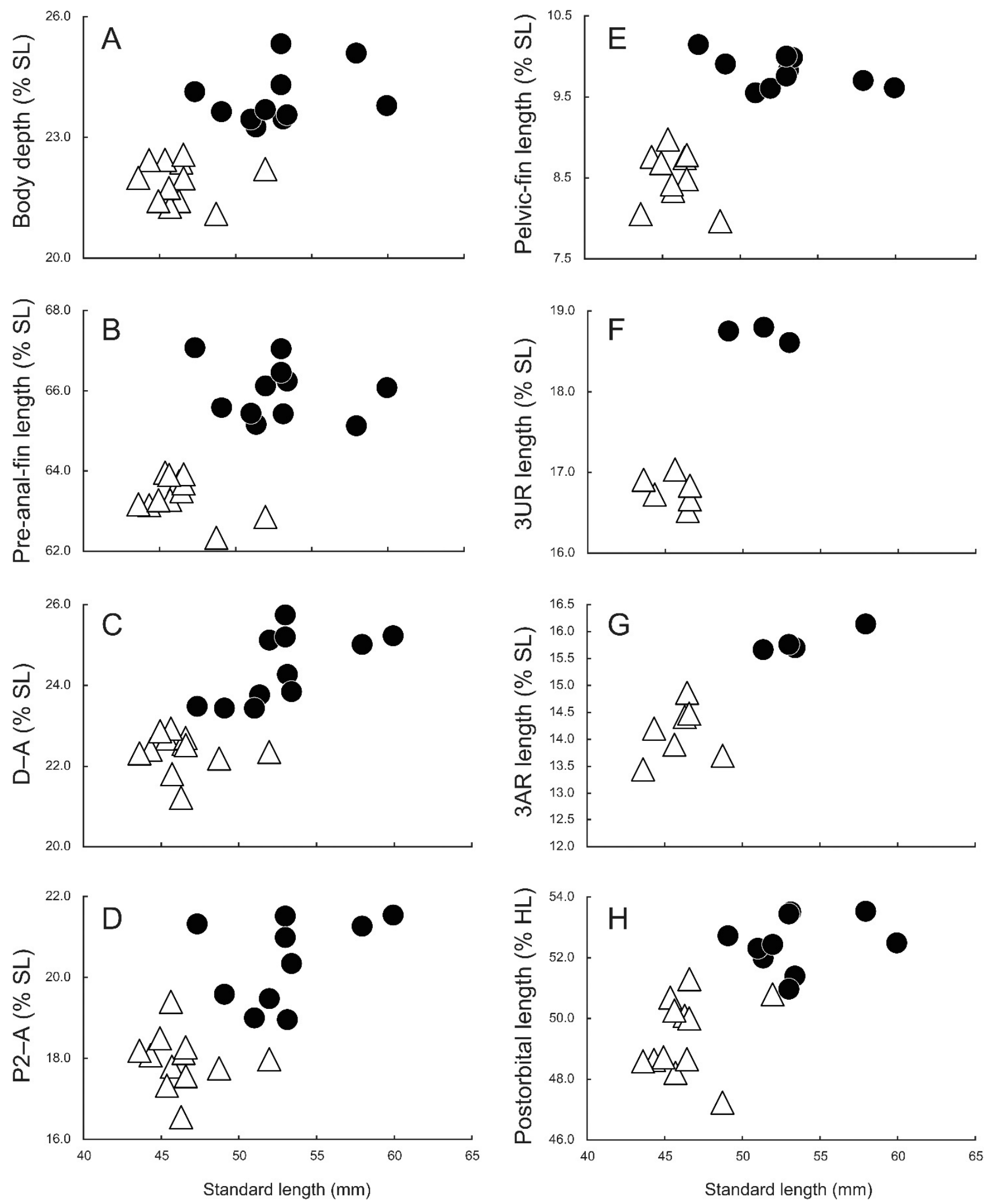

Figure 6. Relationships of (A) body depth (as \% of standard length; SL), (B) preanal-fin length (as \% of SL), (C) distance between origins of dorsal and anal fins (A-D) (as \% of SL), (D) distance between pelvic-fin insertion and anal-fin origin (P2-A) (as \% of SL), (E) pelvic-fin length (as \% of SL), (F) third dorsal-fin ray (3DR) length (as \% of SL), (G) third anal-fin ray (3AR) length (as \% of SL), and (H) postorbital length (as \% of head length) to standard length in Stolephorus ronquilloi (triangles) and $S$. hindustanensis (circles). 
Remarks. Whitehead et al., (1988) [4] stated that some individuals lacked a predorsal scute in their Stolephorus insularis Delsman, 1931 (the authorship was shown as Hardenberg, 1933; the species is currently regarded as S. bengalensis [14]) referring to Wongratana (1980) [22]. Wongratana (1980) [22] also mentioned the lack of predorsal scute of his S. insularis and his list of examined specimens included specimens designated as the type series of S. hindustanensis (the type specimens were registered as BMNH 1969.4.22.1648-1658 at that time). Therefore, individuals of $S$. insularis without predorsal scute in Wongratana (1980) [22] and Whitehead et al., (1988) [4] are probably considered as Stolephorus hindustanensis.

Author Contributions: Both authors collected specimens, worked up data, and wrote the manuscript. All authors have read and agreed to the published version of the manuscript.

Funding: This study was supported in part by JSPS KAKENHI Grant Number 19K23691, JSPS Fellows (DC2: 29-6652), and the Sasakawa Scientific Research Grant from the Japan Science Society (28-745) to HH; JSPS KAKENHI Grant Numbers 20H03311 and 21H03651; the JSPS Core-to-core CREPSUM JPJSCCB20200009; and "Establishment of Glocal Research and Education Network in the Amami Islands" project of Kagoshima University adopted by the Ministry of Education, Culture, Sports, Science and Technology, Japan to HM.

Data Availability Statement: The datasets generated during and/or analyzed during the current study are available from the corresponding author on request.

Acknowledgments: We thank O. Crimmen, J. Maclaine, and N. Martin (BMNH), K. Matsuura, G. Shinohara, M. Nakae (NSMT), and J. Williams, K. Murphy, S. Raredon, and D. Pitassy (USNM) for opportunities to examine specimens of Stolephorus. We also thank G. Hardy (Ngunguru, New Zealand) for reading the manuscript and providing help with English.

Conflicts of Interest: The authors declare no conflict of interest.

\section{References}

1. Wongratana, T. Diagnoses of 24 new species and proposal of a new name for a species of Indo-Pacific clupeoid fishes. Japan. J. Ichthyol. 1983, 29, 385-407.

2. Wongratana, T. Four new species of clupeoid fishes (Clupeidae and Engraulidae) from Australian waters. Proc. Biol. Soc. Washington 1987, 100, 104-111.

3. Wongratana, T. Two new species of anchovies of the genus Stolephorus (Engraulidae), with a key to species of Engraulis, Encrasicholina, and Stolephorus. Am. Mus. Novit. 1987, 2876, 1-8.

4. Whitehead, P.J.P.; Nelson, G.J.; Wongratana, T. FAO species catalogue Vol. 7. Clupeoid fishes of the world (suborder Clupeoidei). An annotated and illustrated catalogue of the herrings, sardines, pilchards, sprats, shads, anchovies and wolf-herrings. Part 2-Engraulididae. FAO Fish. Synop. 1988, 7, 305-579.

5. Wongratana, T.; Munroe, T.A.; Nizinski, M.S. Engraulidae. Anchovies. In FAO Species Identification Guide for Fishery Purposes. The Living Marine Resources of the Western Central Pacific, Vol. 3. Batoid Fishes, Chimaeras and Bony Fishes Part 1 (Elopidae to Linophrynidae); Carpenter, K.E., Niem, V.H., Eds.; Food and Agriculture Organization of the United Nations: Rome, Italy, $1999 ;$ pp. $1698-1753$.

6. Kimura, S.; Hori, K.; Shibukawa, K. A new anchovy, Stolephorus teguhi (Clupeiformes: Engraulidae), from North Sulawesi, Indonesia. Ichthyol. Res. 2009, 56, 292-295. [CrossRef]

7. Hata, H.; Motomura, H. Stolephorus continentalis, a new anchovy from the northwestern South China Sea, and redescription of Stolephorus chinensis (Günther 1880) (Clupeiformes: Engraulidae). Ichthyol. Res. 2018, 65, 374-382. [CrossRef]

8. Hata, H.; Motomura, H. Stolephorus insignus, a new anchovy from the western Pacific, and redescription of Stolephorus apiensis (Jordan and Seale 1906) (Clupeiformes: Engraulidae). Ichthyol. Res. 2018, 66, 280-288. [CrossRef]

9. Hata, H.; Motomura, H. Additional specimens of the poorly known anchovy Stolephorus multibranchus (Clupeiformes: Engraulidae) from Kosrae, Caroline Islands. Biogeography 2018, 20, 78-84. [CrossRef]

10. Hata, H.; Motomura, H. Redescription and distributional range extension of a poorly known anchovy Stolephorus nelsoni (Actinopterygii: Clupeiformes: Engraulidae). Acta Ichthyol. Piscat. 2018, 48, 381-386. [CrossRef]

11. Hata, H.; Motomura, H. Two new species of Stolephorus (Teleostei: Clupeiformes: Engraulidae) from the western Pacific. Raff. Bull. Zool. 2021, 69, 109-117. [CrossRef]

12. Hata, H.; Motomura, H. Stolephorus grandis, a new anchovy (Teleostei: Clupeiformes: Engraulidae) from New Guinea and Australia. Zootaxa 2021, 5004, 481-489. [CrossRef] [PubMed]

13. Hata, H.; Motomura, H. A new species of the anchovy genus Stolephorus Lacepède 1803 from North Sumatra, Indonesia, and redescriptions of Stolephorus pacificus Baldwin 1984 and Stolephorus teguhi Kimura, Hori and Shibukawa 2009 (Teleostei: Clupeiformes: Engraulidae). Zool. Stud. 2021, 60, 65. [CrossRef] 
14. Hata, H.; Lavoué, S.; Motomura, H. Taxonomic status of seven nominal species of the anchovy genus Stolephorus described by Delsman (1931), Hardenberg (1933), and Dutt and Babu Rao (1959), with redescriptions of Stolephorus tri (Bleeker 1852) and Stolephorus waitei Jordan and Seale 1926 (Clupeiformes: Engraulidae). Ichthyol. Res. 2019, 67, 7-38. [CrossRef]

15. Hata, H.; Lavoué, S.; Motomura, H. Stolephorus babarani, a new species of anchovy (Teleostei: Clupeiformes: Engraulidae) from Panay Island, central Philippines. Zootaxa 2020, 4718, 509-520. [CrossRef] [PubMed]

16. Hata, H.; Lavoué, S.; Motomura, H. Stolephorus acinaces, a new anchovy from northern Borneo, and redescription of Stolephorus andhraensis Babu Rao, 1966 (Clupeiformes: Engraulidae). Mar. Biodivers. 2020, 50, 1-11. [CrossRef]

17. Hata, H.; Lavoué, S.; Motomura, H. Taxonomic status of nominal species of the anchovy genus Stolephorus previously regarded as synonyms of Stolephorus commersonnii Lacepède 1803 and Stolephorus indicus (van Hasselt 1823), and descriptions of three new species (Clupeiformes: Engraulidae). Ichthyol. Res. 2021, 68, 327-372. [CrossRef]

18. Gangan, S.S.; Pavan-Kumar, A.; Jahageerdar, S.; Jaiswar, A.K. A new species of Stolephorus (Clupeiformes: Engraulidae) from the Bay of Bengal, India. Zootaxa 2021, 4743, 561-574. [CrossRef] [PubMed]

19. Hata, H.; Motomura, H. A new species of anchovy, Encrasicholina auster (Clupeiformes: Engraulidae) from Fiji, southwestern Pacific Ocean. N. Zeal. J. Zool. 2017, 44, 122-128. [CrossRef]

20. Sabaj, M.H. Codes for natural history collections in ichthyology and herpetology. Copeia 2020, 108, 593-669. [CrossRef]

21. Munroe, T.A.; Nizinski, M.S. Clupeiformes. In A Checklist of the Fishes of the South China Sea; Randall, J.E., Lim, K.K.P., Eds.; National University of Singapore: Singapore, 2000; pp. 569-667.

22. Wongratana, T. Systematics of Clupeoid Fishes of the Indo-Pacific Region. Ph.D. Thesis, University of London, London, UK, 1980. 